\title{
Dampak Ekonomi Pengembangan Daya Tarik Wisata “Hot Spring” Di Kecamatan Marobo, Kabupaten Bobonaro, Timor-Leste
}

Gracita Chiana do Rêgo Cornélio da Piedade a, 1, I Putu Anom a, 2

${ }^{1}$ chytapiedade24@gmail.com, ${ }^{2}$ putuanom@unud.ac.id

a Program Studi Sarjana Destinasi Pariwisata, Fakultas Pariwisata, Universitas Udayana, Jl. Dr. R. Goris, Denpasar, Bali 80232 Indonesia

\begin{abstract}
The economic impact of development of Marobo District's "Hot Spring" in the municipality of Bobonaro, Timor-Leste. In this case, tourism sector in the Bobonaro Municipality has sufficient potential to be developed and it is a tourism sector. The torurism contributes to the increase income of the area and signifies by the movement growth of the economic in Marobo district.. The purpose of the research are (1) to fine the potensial attraction of the natural tourism of "hot spring" Marobo, municipality of Bobonaro, Timor-Leste. (2) To discover the economic impact of the natural attarction "hot spring"development in Marobo, municipality of Bobonaro, Timor-Leste.

In this research used both quantitative and qualitative data collecting by observation, documentatios, and interview. The result of the research has show that Marobo Hot spring has natural, cultural and man-made supply potential as tourism attraction. However, the development of Marobo hot spring give economic impact such as, increasing local income, employed opportunities, impact on development and government revenue.

Some suggestion will be given for tourist. They should keep the environtment in Marobo Hot spring. Also they have to follow the local regulation in Marobo Hot Spring. The government should offer the good facilities for tourist that can fulfil their need when visited Marobo Hot Spring.
\end{abstract}

\section{Keywords : economic impact, development, tourist attraction, hot spring}

\section{PENDAHULUAN}

Sektor pariwisata, sebagai kegiatan perekonomian telah menjadi andalan dan prioritas pengembangan bagi sejumlah Negara. Negara Timor-Leste, merupakan Negara yang baru berkembang, namun memiliki banyak daya tarik wisata yang cukup besar, banyaknya keindahan alam, aneka warisan sejarah budaya dan kehidupan masyarakat.

Cohen (1984) dalam Pitana (2009) menyatakan bahwa pariwisata terhadap kondisi sosial ekonomi masyarakat lokal memperoleh bagian yang dapat menjadi delapan kelompok besar, yaitu dampak terhadap penerimaan devisa, dampak terhadap pendapatan pemerintah, harga-harga, distribusi manfaat/keuntungan, kesempatan kerja kepemilikan dan control, pembangunan pada umumnya, dan pendapatan masyarakat. Kecamatan Marobo adalah salah satu kecamatan yang terletak di Kabupaten Bobonaro. Berdekatan dengan wilayah perbatasan Indonesia dan Timor-Leste yang memiliki banyak daya tarik wisata alam yang saaat ini merupakan tujuan wisata.

Terdapat potensi wisata yang berada di Kabupaten Bobonaro seperti: Hot Spring Bee
Banas dan Bee Dois Boroluli . Saat ini Hot Spring Bee Banas dan Bee Dois Boroluli sudah dikenal oleh wisatawan mancanegara maupun domestik yang memiliki potensi alam serta keunikan yang sangat menarik untuk dikunjungi. Dari potensi wisata serta keunikan yang dimiliki membuat masyarakat lokal serta pemerintah mendapatkan keuntunggan dari retribusi karcis yang dari tahun ke tahun terus meningkat.

Dengan potensi daya tarik wisata hot spring dan aktivitas wisata yang ada di Marobo, peneliti ingin menguraikan dampak positif dan negatif ekonomi bagi masyarakat Marobo yang ditimbulkan dari pengembangan hot spring tersebut.

Adapun dampak setelah pengembangan daya tarik wisata "hot spring" Marobo, yaitu dampak positif dan dampak negatif. Dampak positif yang dilakukan di daya tarik wisata " $\mathrm{Hot}$ Spring" Marobo dengan adanya kegiatan pariwisata maka tercipta pula lapangan kerja untuk masyarakat sekitar yang dimana dapat menguntungkan bagi masyarakat lokal. Kehidupan sehari-hari masyarakat sekitar sebagai petani namun tidak menutup kemungkinan masyarakat sekitar ikut andil 
dalam kegiatan pembangunan pariwisata yang dapat memberikan atau menambah penghasilan yang bersifat positif bagi kehidupan masyarakat lokal lebih baik lagi.

Berdasarkan latar belakang menyadari bahwa masih adanya bervariasi dan penafsiran terhadap permasalahan penilitian : Dampak Ekonomi Pengembangan Daya Tarik Wisata "Hot Spring" di Kecamatan Marobo, Kabupaten Bobonaro, Timor-Leste. Dari permasalahan tersebut diatas dapat dirumuskan masalah sebagai berikut:

1. Apa saja potensi yang dimiliki di daya tarik wisata alam "hot spring" di Kecamatan Marobo, Kabupaten Bobonaro, Timor-Leste?

2. Bagaimana dampak ekonomi pengembangan daya tarik wisata alam "hot spring" di Kecamatan Marobo, Kabupaten Bobonaro, Timor-Leste?

\section{KEPUSTAKAAN}

\subsection{Telaah Hasil Penelitian Sebelumnya}

Telaah penelitian yang digunakan pada penelitian ini yaitu jurnal yang ditulis oleh Barreto (2015) dengan judul "Strategi Pengembangan obyek Wisata Air Panas di Desa Marobo, Kabupaten Bobonaro, Timor-Leste", Penelitian selanjutnya yaitu jurnal penelitian yang dilakukan oleh Suherman (2009) yang berjudul "Dampak Sosial Ekonomi Pembangunan dan Pengembangan Pelabuhan Perikanan Nusantara (PPN) Pengambengan Jembrana Bali", ketiga yaitu jurnal Anggraeni (2013) yang berjudul "Analisis Dampak Ekonomi Wisata Bahari Terhadap Pendapatan Masyarakat di Pulau Tidung" dan yang terakhir yaitu penelitian dari jurnal Ekayani Dkk. (2014) yang berjudul "Wisata Alam Taman Nasional Gunung Halimung Salak: Solusi Kepentingan Ekologi Dan Ekonomi".

\subsection{Landasan Konsep Analisis}

\subsubsection{Konsep Pengembangan}

Menurut Paturusi

mengungkapkan bahwa "pengembangan adalah suatu strategi yang di pergunakan untuk memajukan, memperbaiki dan meningkatkan kondisi kepariwisataan suatu objek dan daya tarik wisata sehingga dapat dikunjungi wisatawan serta mampu memberikan manfaat bagi masyarakat disekitar objek dan daya tarik wisata maupun pemerintah".

\subsubsection{Konsep Potensi Wisata}

Potensi wisata merupakan suatu kawasan yang dimana memiliki kekuatan yang dapat dipergunakan untuk perluasan, seperti manusia, alam dan hasil karya manusia (Sujali dalam Amdani 2008).

Terdapat tiga Potensi wisata yang dapat dilihat seperti:

1. Potensi Wisata Alam

Yang dimaksud dengan potensi wisata alam berupa bentuk, jenis fauna dan flora suatu daerah, bentang alam seperti pegununggan, pantai, hutan dan lain-lain (keadaan fisik suatu daerah).

\section{Potensi Wisata Kebudayaan}

Merupakan potensi wisata kebudayaan adalah semua rasa, hasil cipta dan karsa manusia yang berupa adat-istiadat, kesenian, kerajinan tangan, peninggalan sejarah berupa bangunan (contoh monumen).

3. Potensi Wisata Buatan Manusia

Potensi wisata buatan manusia juga sebagai daya tarik wisata berupa, pertunjukan tarian, persembahan seni budaya di suatu wilayah.

\subsubsection{Konsep Daya Tarik Wisata}

Berdasarkan Undang-Undang Republik Indonesia No.10 tahun 2009, Daya Tarik Wisata adalah segala sesuatu yang mempunyai ciri khas, kesederhanaan, dan makna yang berupa keanekaragaman kekayaan alam, budaya dan buatan yang menjadi sasaran untuk dikunjungi oleh wisatawan. Daya tarik wisata terbagi menjadi tiga macam yaitu daya tarik wisata alam, budaya dan buatan. Namun disini peneliti hanya fokus mengambil daya tarik wisata alam.

\section{METODE}

Dalam metode penelitian ini dilakukan di "Hot Spring" Marobo yang berada di Ilat-Laun. Metode yang digunakan yaitu deskriptif kualitatif yang berfokus terhadap dampak ekonomi pengembangan daya tarik wisata di Hot Spring Marobo . Data primer yang dimaksud yaitu data mengenai potensi wisata yang ada di daya tarik wisata "hot spring" Marobo yang didapat dari observasi dan wawancara. Teknik analisis data yang digunakan dalam penelitian ini yaitu teknik analisis data model alir dimana data terkait dengan dampak ekonomi pengembangan daya tarik wisata "hot spring" di kecamatan Marobo, 
kabupaten Bobonaro, Timor-Leste sehingga bisa menjadi sebuah kesimpulan dampak pengembangan daya tarik wisata hot spring Marobo.

\section{IV.HASIL DAN PEMBAHASAN}

\subsection{Potensi Wisata di Daya Tarik Wisata Hot Spring \\ a. Potensi alam}

Marobo Hot Spring merupakan wisata air panas yang baru diresmikan pada tanggal 8 Desember 2016 oleh Pemerintah Republik Demokratik Timor-Leste, dalam hal ini SEPFOPE (Secretaria do Estado Política Formação Profecional e Emprego) yang diberi nama dengan "Turismo Comunitária" (Pariwisata berbasis masyarakat). Dengan dibangunnya infrastruktur ini, air panas (hot spring) Marobo sudah dapat dinikmati oleh wisatawan, walaupun kegatan pembangunannya masih dalam proses penyelesaian. Meskipun demikian, banyak wisatawan yang terus berdatangan mengunjungi air panas tersebut.

b. Potensi budaya

Adapun potensi budaya seperti menenun kain tradisional yang dinamai Tais yang berwarna hitam khas masyarakat Marobo yang dapat dilihat dan menjadi sebuah wisata edukasi bagi wisatawan yang ingin mempelajari menenun dan juga terdapat rumah adat asli penduduk yang tinggal di sekitar air panas (hot spring) Marobo di daya tarik wisata air panas (hot spring) Marobo.

c. Potensi buatan

Di sekitar jalan menuju air panas juga terdapat bangunan tua yang dulu dibangun oleh koloni Portugis yang dulu dijadikan hospital karena dekat dengan sumber air panas yang juga dipakai untuk penyembuhan. Selain itu, dulu bangunan tersebut dijadikan tempat beristirahatnya para dokter, karena keindahan alam sekitar yang asri. Namun sekarang tempat tersebut menjadi peninggalan yang digunakan untuk spot berfoto bagi wisatawan.

\subsection{Dampak Ekonomi Pengembangan Daya Tarik wisata alam hotspring di kecamatan marobo Timor-Leste}

\subsubsection{Dampak terhadap pendapatan masyarakat}

Dengan meningkatnya jumlah kunjungan wisatawan di daya tarik wisata Air Panas (hot spring) Marobo, dapat memberikan dampak positif terhadap pendapatan masyarakat setempat. Adapun usaha-usaha kecil di sekitar kawasan daya tarik wisata (hot spring) Marobo yang berupa penjualan makanan dan minuman.

Saat ini wisata Air Panas (hot spring) Marobo sangat memberikan dampak yang baik terhadap pendapatan masyarakat lokal yang dulunya hanya petani biasa tetapi kini sudah dapat beralih profesi sebagian menjadi pedagang, penjaga parkir serta mengawasi di kawasan daya tarik wisata Air Panas (hot spring) Marobo. Dengan adanya wisatawan yang berkunjung dapat memberikan dampak positif yang sangat signifikan dalam pendapatan masyarakat lokal yaitu dengan cara membeli produk lokal yang dijual oleh masyarakat lokal, yang tingkat perekonomiannya mulai membaik sehingga masyarakat makmur dan dapat menekan angka kemiskinan dan pengangguran dan lain-lain sebagainya.

Adapun dampak negatifnya terhadap pendapatan masyarakat di daya tarik wisata Air Panas (hot spring) Marobo karena wisatawan yang berkunjung ke daya tarik wisata alam tersebut mereka membawa makanannya sendiri sehingga pedagang merasa dirugikan karena dagangannya tidak laku terjual.

\subsubsection{Dampak Terhadap Kesempatan Kerja \\ Adapun pembangunan fasilitas} penunjang pariwisata yang disediakan berdasarkan kesepakatan bersama antara masyarakat lokal sama Pemerintah (SEPFOPE), dapat memberikan peluang kesempatan kerja untuk masyarakat lokal yang dulunya belum mempunyai pekerjaan tetap.

Setelah adanya fasilitas pendukung yang disediakan maka dapat memberikan peluang usaha kepada masyarakat lokal dalam hal ini masyarakat lokal meyediakan sendiri fasilitas untuk berjualan seperti kios kecil disekitar kawasan Air Panas (hot spring) Marobo. 
Namun dalam peluang yang didapatkan dari pemerintah SEPFOPE ada dampak negatif terhadap pembangunan pariwisata seperti tidak adanya tempat yang layak bagi masyarakat lokal untuk berjualan disana dan juga pemerintah belum menyediakan transportasi yang layak bagi pedagang.

\subsubsection{Dampak Terhadap Pembangunan Pada Umumnya}

Dengan adanya persediaan fasilitas pendukung yang sudah dibangun di daya tarik wisata Air panas (hot spring) Marobo, maka pada umumnya pembangunan berkembang pesat. Misalnya : pembangunan infrastruktur jalan menuju tempat wisata, tempat parkir, kamar mandi umum dan juga tempat untuk bersantai bagi wisatawan yang berkunjung.

Meskipun begitu fasilitas-fasilitas tersebut tidak digunakan dengan baik oleh wisatawan maupun masyarakat lokal, seperti tidak adanya kesadaran dalam menjaga fasilitas tersebut agar dapat digunakan dan keamanan disana juga tidak terjamin karena masyarakat tinggal berjauhan dari daya tarik wisata Air Panas (hot spring) Marobo sehingga fasilitas tersebut tidak terawat dan tidak terlindungi dengan baik.

\subsubsection{Dampak Terhadap Pendapatan Pemerintah}

Tersedianya fasilitas yang memadai di daya tarik wisata "hot spring" Marobo kerjasama antara masyarakat sekitar dengan Pemerintah Turismo Comunitária (pariwisata berbasis masyarakat), maka Pendapatan Asli Daerah (PAD) dengan sendirinya dapat meningkat dengan adanya peningkatan kunjungan wisatawan. Dari retribusi ini dapat meningkatkan Pendapatan Pemerintah yang dimaksud dapat diperoleh melalui : Retribusi Karcis Masuk wilayah "Hot Sring" Marobo dan Retribusi bagi kedai/kios yang disediakan oleh masyarkat lokal.

Namun adapun dampak negatifnya terhadap aksesibilitas menuju daya tarik wisata "Hot Spring" tersebut yang mengakibatkan PADnya menurun karena banyak wisatawan belum mengetahui lokasi wisata alam tersebut hal ini disebabkan kurangnya perhatian dari pemerintah terhadap informasi berupa brosur, akses jalan menuju lokasi masih dalam kondisi yang kurang baik, maka banyak wisatawan tidak dapat berkunjung ke lokasi tersebut.

Tabel 4.1. Tarif Kendaraan

\begin{tabular}{|l|c|c|}
\hline No & Jenis & Tarif \\
\hline $\mathbf{1 .}$ & Beroda dua (Motor) & Rp 10.000-, \\
\hline $\mathbf{2 .}$ & $\begin{array}{c}\text { Beroda empat } \\
\text { (Mobil) }\end{array}$ & Rp 50.000-, \\
\hline
\end{tabular}

Sumber : Peneliti 2019

\section{SIMPULAN DAN SARAN \\ 5.1 Simpulan}

Berdasarkan hasil analisis yang

dilakukan didapatkan beberapa simpulan

diantaranya :

Dampak positif:

Dampak ekonomi pengembangan daya tarik wisata "hot spring" Marobo yaitu :

a. Dampak terhadap pendapatan masyarakat yang didapat dari usaha menjual makanan dan minuman di daya tarik wisata hot spring marobo

b. Dampak terhadap kesempatan kerja msayarakat lokal yang dulunya tidak memiliki pekerjaan setelah adanya wisatawan di Marobo mereka memiliki pekerjaan sebagai pedagang, tukang parkir dan menggelola daya tarik tersebut.

c. Dampak terhadap pembangunan dapat dilihat dari pembangunan fasilitas pendukung di daya tarik wisata "Hot Spring" Marobo

d. Dampak terhadap pendapatan pemerintah terlihat dari meningktanya kjumlah kunjungan wisatawan sehingga memberikan kontribusi dari retribusi yang ada.

Dampak negatif:

a. Aksesibilitas menuju lokasi masih dalam perbaikan

b. Penerangan jalan dan kebersihan

c. Pemasaran atau promosi mengenai obyek wisata masih kurang

d. Sarana transportasi umum belum tersedia

\subsection{Saran}

Bagi wisatawan diperlukan kesadaran maupun masyarakat lokal untuk lebih memperhatikan lingkungan sekitar dengan 
tidak membuang sampah sembarangan agar alam dapat memberikan kesejukan dan bersahabat dengan kita. Pemerintah hendaknya membuat suatu peraturan berupa papan yang tertulis larangan di wilayah " $\mathrm{Hot}$ Spring" Marobo yang mengatur tentang larangan bagi wisatawan agar tidak membawa snack berupa Makanan/Minuman dan memasuki wilayah obyek wisata, yang mana dapat merugikan pihak pedagang yang berjualan di sekitar daya tarik wisata "Hot Spring" Marobo.

Diharapkan juga untuk pemerintah dapat membuat fasilitas yang sesuai dengan kebutuhan wisatawan agar bangunan tersebut dapat dipakai atau dapat digunakan oleh wisatawan.

\section{DAFTAR PUSTAKA}

Amdani Suut, 2008. Analisis Potensi Obyek Wisata Alam Pantai di Kabupaten Gunung Kidul.

Anggraeni, A. A. (2013). Analisis Dampak Ekonomi Wisata Bahari terhadap Pendapatan Masyarakat di Pulau Tidung. Reka Loka.

Barreto, M., \& Giantari, I. G. A. (2016). Strategi Pengembangan Objek Wisata Air Panas Di Desa Marobo, Kabupaten Bobonaro, Timor Leste. E-Jurnal Ekonomi dan Bisnis Universitas Udayana.

Ekayani, M., Yasmin, R., Sinaga, F., \& La Ode, M. M. (2014). Wisata Alam Taman Nasional Gunung Halimun Salak: Solusi Kepentingan Ekologi dan Ekonomi. Jurnal Ilmu Pertanian Indonesia.

Paturusi, Samsul A. (2001). Perencanaan Tata Ruang Kawasan Pariwisata.

Pitana, I Gde. Diarta, I Ketut Surya.2009. Pengantar Ilmu Pariwisata. Jakarta: Penerbit Andi

Suherman, A., \& Dault, A. (2011). Dampak Sosial Ekonomi Pembangunan dan Pengembangan Pelabuhan Perikanan Nusantara (PPN) Pengambengan Jembrana Bali. Jurnal Saintek Perikanan.

Undang-undang Republik Indonesia No.10 Tahun 2009

Tentang Kepariwisataan 